\title{
MEMAHAMI ARAH BARU SUPERVISI PENDIDIKAN SEBAGAI TINDAKAN MORAL
}

\author{
Oleh : \\ Muhamad Abdul Manan \\ Fakultas Tarbiyah IAI Ibrahimy Situbondo \\ mananmanis@gmail.com
}

\begin{abstract}
:
Education is important of issue for every aspect progress, human development and especially for our big nation. The context school is as education organization that needs supervision and assessment.The main role of superior is as coordinator, consultant, leader of club, and evaluator. Work of coordinator is as program which managed by staff member for studying and teaching. Work of consultant is giving help and consulate of problems experienced by teacher as individual or collective. Work of leader club is lead of teachers for developing cub potency when they develop of curriculum, subject and teacher professional needs.

Executor is leader of supervision, supervisor and supervisor. They are responsible supervisor for existence and dynamics school as institution then hoped can be awaken nation potential in future. Superiors working considered for involve moral dynamics. Superiors moral activity have relationship by environment; as teachers relation and most urgent are relation to students and moral intrinsic of learning supervisor. No realize, sometimes supervision process did by supervisor which have moral element; basic moral of dimension must visible clear and assertive applied.
\end{abstract}

Key Words: Supervisi, Pendidikan dan Tindakan Moral

\section{A. Pendahuluan}

Pendidikan merupakan persoalan penting bagi setiap segi kamajuan dan perkembangan manusia pada khusunya dan bangsa pada umumnya. Kemajuan dalam segi pendidikan sangat menentukan kualitas sumber daya manusia dan perkembangan bangsa kearah lebih baik. Dalam rangka perbaikan mutu pendidikan, pemerintah telah melakukan perbaikan kurikulum, peningkatan mutu guru, penyedian sarana dan prasarana, perbaikan kesejahteraan guru, perbaikan organisasi sekolah, perbaikan manajemen, pengawasan dan perundang-undangan.

Tujuan pendidikan adalah untuk meningkatkan kualitas sumber 
daya manusia sebagaimana yang telah digariskan melalui Undang Undang Sistem Pendidikan Nasional No. 20 Tahun 2003 bertujuan untuk berkembangnya potensi peserta didik agar menjadi manusia yang beriman dan bertaqwa kepada Tuhan Yang Maha Esa, berakhlak mulia, sehat, berilmu, cakap, kreatif mandiri, dan menjadi warga negara yang demokratis serta bertanggung jawab. Salah satu usaha untuk meningkatkan kualitas sumber daya manusia ialah melalui proses pembelajaran di sekolah.

Dalam usaha meningkatkan kualitas sumber daya pendidikan, guru merupakan komponen sumber daya manusia yang harus dibina dan dikembangkan terus menerus. Tidak semua guru yang dididik di lembaga pendidikan terlatih dengan baik dan kualified. Potensi sumber daya guru itu perlu terus menerus bertumbuh dan berkembang agar dapat melakukan fungsinya secara profesional. Selain itu, pengaruh perubahan yang serba cepat mendorong guru-guru untuk terus menerus belajar menyesuaikan diri dengan perkembangan ilmu pengetahuan dan teknologi serta mobilitas masyarakat. Itulah sebabnya ulasan mengenai perlunya supervisi pendidikan itu bertolak dari keyakinan dasar bahwa guru adalah suatu profesi.

Dalam konteks sekolah sebagai sebuah organisasi pendidikan, supervisi merupaka bagian dari proses administrasi dan manajemen. Kegiaan supervisi melengkapi fungsi-fungsi administrasi yang ada di sekolah sebagai fungsi terakhir, yaitu penilaian terhadap semua kegiatan dalam mencapai tujuan. Dengan supervisi, akan memberikan inspirasi untuk bersama-sama menyelesaikan pekerjaan-pekerjaan dengan jumlah lebih banyak, waktu lebih cepat, cara lebih mudah, dan hasil yang lebih baik daripada jika dikerjakan sendiri. Supervisi mempunyai peran mengoptimalkan tanggung jawab dari semua program. Supervisi bersangkut paut dengan semua upaya penelitian yang tertuju pada semua aspek yang merupakan faktor penentu keberhasilan. Dengan mengetahui kondisi aspek-aspek tersebut secara rinci dan akurat, dapat diketahui dengan tepat pula apa yang diperlukan untuk meningkatkan kualitas organisasi yang bersangkutan.

Tanpa disadari, terkadang proses pengawasan yang dilakukan oleh seorang supervisor telah memiliki unsur moral di dalamnya; suatu dasar dimana dimensi moral harus lebih jelas terlihat atau tegas diterapkan. Selanjutnya, perlu digali posisi institusional para supervisor dan kontribusi mereka dalam menciptakan sebuah komunitas moral di sekolah. Jika pekerjaan supervisor dilekatkan pada kelangsungan moral yang beragam di sekolah, mungkin disebabkan 
dalam rangka menjawab dan mendukung karakter moral dari pembelajaran itu sendiri dimana pekerjaan supervisor dilihat paling konsisten untuk menerapkannya.

\section{B. Pengertian Supervisi}

Secara etimologi supervisi berasal dari kata super dan vision yang mengandung arti melihat dan meninjau dari atas atau menilik dan menilai dari atas untuk menilai aktifitas, kreativitas, dan kinerja bawahan. Menurut P. Adams dan Frank G. Dickey, supervisi adalah program yang berencana untuk memperbaiki pengajaran. Inti dari supervisi pada hakekatnya adalah memperbaiki hal belajar dan mengajar. Program ini dapat berhasil bila supervisor memiliki ketrampilan (skill) dan cara kerja yang efisien dalam kerjasama dengan orang lain (guru dan petugas pendidikan lainnya). ${ }^{1}$

Sedangkan menurut Boardman: supervisi merupakan suatu usaha menstimulir, mengkoordinir, dan membimbing secara kontinu pertumbuhan guru-guru sekolah, baik secara individuil maupun secara kolektif, agar lebih mengerti, dan lebih efektif dalam mewujudkan seluruh fungsi pengajaran, sehingga dengan demikian mereka mampu dan lebih cakap berpartisipasi dalam masyarakat demokrasi modern. ${ }^{2}$

Dewasa ini, menurut Sahertian, supervisi adalah berkembang dari yang bersifat tradisional menjadi supervisi yang bersifat ilmiah, sebagai berikut: Sistematis, artinya dilakukan secara teratur, berencana, dan kontinu. Objektif, artinya ada data yang didapat berdasarkan observasi nyata, bukan berdasarkan tafsiran pribadi. Menggunakan alat pencatat yang dapat memberikan informasi sebagai umpan balik untuk mengadakan penilaian terhadap proses pembelajaran dikelas. ${ }^{3}$

Menurut $\mathrm{H}$. Mukhtar dan Iskandar, supervisi adalah mengamati, mengawasi, atau membimbing, dan memberikan stimulus kegiatankegiatan yang dilakukan oleh orang lain dengan maksud mengadakan perbaikan. Konsep supervisi didasarkan pada keyakinan bahwa perbaikan merupakan suau usaha yang cooperative dari semua orang yang berpartisipasi dan supervisor sebagai pemimpin, yang bertindak sebagai stimulator, pembimbing, dan konsultan bagi para bawahannya dalam

1Piet A Sahertian dan Drs Frans Mataheru Dip. Ed. Ad, Prinsip dan Teknik Supervisi Pendidikan (Surabaya: Usana Offset Printing, 1981), hlm. 18.

${ }^{2}$ Nurhayati, Djamas, Pedoman Pelaksanaan Supervisi (Jakarta: Departemen Agama RI Direktorat Jenderal Pembinaan Kelembagaan Agama Islam, 2000), hlm.9.

3 A. Piet Sahertian, konsep dasar dan teknik supervise pendidikan dlamrangka pengembangan SDM (Jakarta: rineka cipta, 2008 ), hlm. 16. 
rangka perbaikan tersebut. Supervisi pendidikan adalah usaha mengkoordinasi dan membimbing pertumbuhan guru-guru disekolah secara kontinu, baik secara individu maupun kelompok. Bantuan apapun ditunjukan demi terwujudnya perbaikan dan pembinaan aspek pengajaran. 4

Peraturan Menteri Pendidikan Nasional Nomor 12 Tahun 2007 tentang Standar Pengawas Sekolah/Madrasah berisi standar kualifikasi dan kompetensi pengawas sekolah. Standar kualifikasi menjelaskan persyaratan akademik dan nonakademik untuk diangkat menjadi pengawas sekolah. Standar kompetensi memuat seperangkat kemampuan yang harus dimiliki dan dikuasai pengawas sekolah untuk dapat melaksanakan tugas pokok, fungsi dan tanggung jawabnya.

Ada enam dimensi kompetensi yang harus dikuasai pengawas sekolah yakni: (a) kompetensi kepribadian, (b) kompetensi supervisi manajerial, (c) kompetensi supervisi akademik, (d) kompetensi evaluasi pendidikan, (e) kompetensi penelitian dan pengembangan, dan (f) kompetensi sosial. Salah satu poin kompetensi yang harus dimiliki yang termasuk dalam dimensi kompetensi supervisi manajerial, adalah menyusun metode kerja dan instrumen yang diperlukan untuk melaksanakan tugas dan fungsi pokok pengawasan di sekolah ${ }^{5}$.

Dari beberapa pengertian tersebut, dapat diambil beberapa catatan penting dalam kegiatan supervisi. Pertama, ada perhatian lebih dari atasan untuk membangkitkan kualitas dunia pendidikan dengan meningkatkan kualitas aktor paling penting yang langsung berinteraksi dengan anak didik, yaitu guru. Perhatian ini melahirkan usaha yang dilakukan secara sistematis, kontinu, dan konsisten. Kedua, adanya kerjasama aktif antara supervisor dengan guru untuk mengembangkan dunia pendidikan, tidak sepihak secara otoriter, sentralistik, dan diskriminatif. Supervisor menampilkan diri sebagai sisi yang mengarahkan, membimbing dan memberdayakan, supaya guru bisa melesat dengan potensi dan gayanya sendiri. Bimbingan profesional yang dilakukan merupakan usaha yang memberikan kesempatan bagi guru-guru untuk berkembang secara profesional, sehingga mereka lebih maju lagi dalam melaksanakan tugas pokoknya, yaitu memperbaiki dan meningkatkan proses belajar muridmurid. Namun, jika supervisor melakukan tindakan yang represif, hasilnya

${ }^{4}$ Mukhtar \& Iskandar, Orientasi Baru Supervise Pendidikan (Jakarta: gaung persada press, 2009), cet. 1 , hlm. 40-41

5 Badan Standar Nasional Pendidikan, Standar Pengawas Sekolah Madrasah (Jakarta: BSNP, 2007), hlm.9.

$240 \mid$ JURNAL LISAN AL-HAL 
kontraproduktif terhadap kualitas pembelajaran. Guru menjadi apatis, bahkan bisa terjadi permusuhan dan terjadi konflik yang berkepanjangan. Apalagi, terhadap guru-guru senior yang sudah lama berkecimpung dalam dunia pendidikan dengan segudang pengalaman lapangan, tentu mereka membutuhkan kearifan, kesantunan, dan kemarahan dalam melakukan interaksi, tidak melakukan intruksi sepihak. Disinilah kedewasaan dan kematangan emosional, intelektual, social, dan spiritual supervisor sangat dibutuhkan dalam melakukan tugas supervisi. Berikut bagan siklus hubungan supervisi, proses mengajar dan hasil belajar, yang dapat menyimpulkan dan juga sebagai gambaran perilaku supervisor dalam tatanan pendidikan.

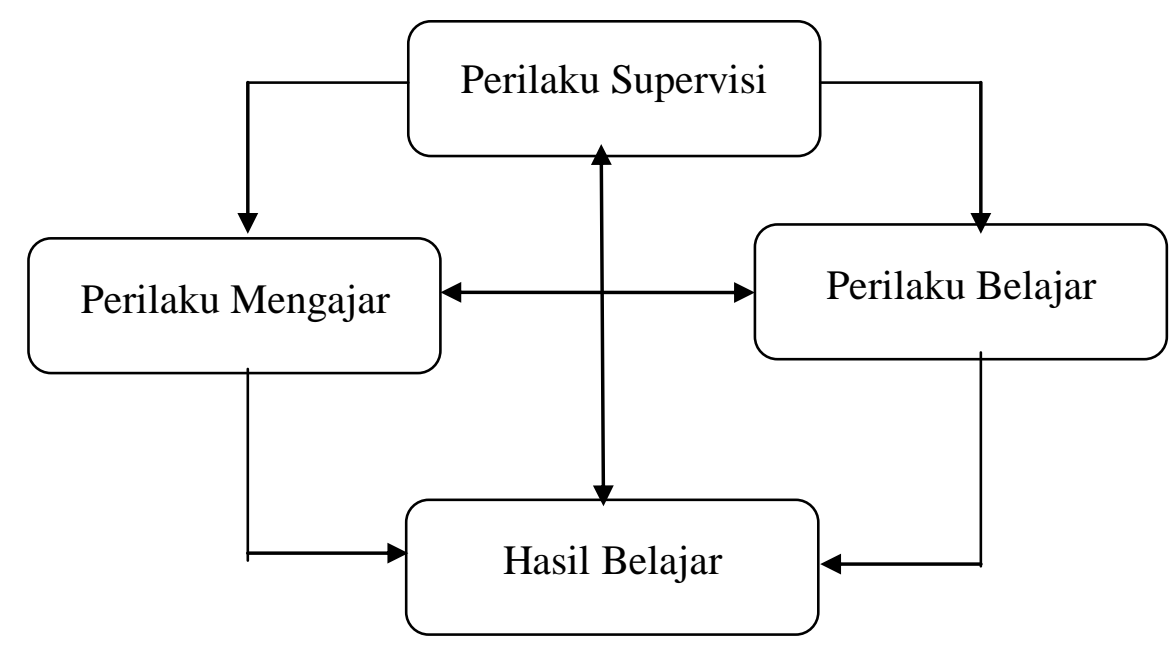

\section{Peran Supervisi Pendidikan}

Eksekutor supervisi dilapangan adalah kepala sekolah, penilik, dan pengawas. Mereka adalah supervisor yang bertanggung jawab terhadap eksistensi dan dinamika sekolah sebagai lembaga pendidikan yang diharapkan mampu membangkitkan potensi bangsa dimasa depan. Peran tiga supervisor tersebut sangat vital bagi pengembangan sekolah di era global sekarang. Tiga supervisor ini mempunyai batas kewenangan masing-masing yang saling melengkapi, tidak bertabrakan dan berseberangan.

Peran utama supervisor adalah sebagai koordinator, konsultan, pemimpin kelompok, dan evaluator. Sebagai koordinator, tugasnya adalah sebagai mengoordinasi program belajar dan mengajar serta tugas anggota staf. Sebagai konsultan, tugasnya adalah memberi bantuan, mengkonsultasikan masalah yang dialami oleh guru secara individual dan 
kolektif. Sebagai pemimpin kelompok, tugasnya adalah memimpin sejumlah staf guru dalam mengembangkan potensi kelompok saat mengembangkan kurikulum, materi pelajaran, dan kebutuhan professional guru-guru secara bersama. Sebagai pemimpin kelompok, ia dapat mengembangkan keterampilan dan kiat-kiat dalam bekerja untuk kelompok (working for the group), bekerja dengan kelompok (working with the group), dan bekerja melalui kelompok (working trough the group). Sedangkan sebagai evaluator tugasnya adalah membantu guruguru dalam menilai hasil dan proses belajar, menilai kurikulum yang sedang dikembangkan, juga belajar menatap dirinya sendiri. ${ }^{6}$

Peranan supervisi sangat tergantung pada tingginya supervisor memerankan diri ditengah komunitasnya. Mampukah ia memimpin anggotanya dengan pemikiran dan gerakannya? Sangupkah ia mengkoordinasi kegiatan yang melibatkan banyak pihak? Dapatkah ia membekali teori dan metode baru kepada anggotanya? Mampukah ia mewujudkan visi dan misi lembaga yang menjadi consensus bersama? Jawaban dari pertanyaan ini adalah medan perjuangan dan pengabdian supervisor di sekolahnya.

\section{Peran kepala sekolah}

Kepala sekolah sebagai supervisor berfungsi sebagai pengawas, pengendali, pembina, pengarah, dan pernberi contoh bagi para guru dan karyawannya di sekolah. Kepala sekolah harus memahami tugas dan kedudukan karyawan-karyawannya atau staf di sekolah yang dipimpinnya sehingga, pembinaan yang dilakukannya berjalan dengan baik dan tidak membingungkan.

Secara ringkas, tugas atau peran kepala sekolah sebagai supervisor ialah sebagai berikut:

a. Merencanakan program tahunan sekolah yang mencakup program pengajaran, kesiswaan, kepegawaian, keuangan, dan penyediaan fasilitas-fasilitas yang diperlukan.

b. Merencanakan program akademik yang fokus pada persiapan program pengajaran. Program ini rneliputi penyediaan kebutuhan guru, pembagian tugas mengajar, dan pengadaan berbagai fasilitas, di antaranya penambahan laboratorium, lapangan olah raga, ekstrakurikuler, dan lain sebagaimya.

${ }^{6}$ Mukhtar \& Iskandar, Orientasi Baru Supervise Pendidikan (Jakarta: gaung persada press, 2009), cet. 1 , hlm. 45-46.

$242 \mid$ JURNAL LISAN AL-HAL 
c. Merencanakan program yang kaitannya dengan kesiswaan. Program ini rneliputi penerimaan siswa baru, sistern seleksi siswa, jumlah siswa yang akan diterima, pengadaan kelas baru, dan lain sebagainya.

d. Merencanakan bidang kepegawaian yang berkaitan dengan penerimaan guru bantu, pengadaan berbagai program yang bertujuan meningkatkan pendidikan guru dalam strategi pembelajaran dan pelatihan, workshop, dan kegiatan lain yang berupaya membina guru dan karyawan agar lebih profesional menjalankan tugas.

e. Dalam bidang pengadaan dana bagi keseluruhan administrasi pendidikan, tugas kepala sekolah di antaranya mengatur pernberian .gaji bagi seluruh pegawai sekolah, mengajukan penambahan dana kepada pihak pemerintah, yayasan, dan lain sebagainya.

f. Merencanakan bidang sarana dan prasarana yang mencakup perbaikan dan penambahan sarana dan prasarana sekolah, seperti lapangan, alat-alat laboratorium untuk praktik siswa, rehabilitasi gedung sekolah, dan lain sebagainya. ${ }^{7}$

Sebagai supervisor, kepala sekolah berkewajiban melakukan koordinasi atas seluruh kegiatan dan adrninistrasi sekolah, Ia harus menghubungkan seluruh personal organisasi dengan tugas yang dilakukannya sehingga terjalin kesatuan, keselarasan, serta menghasilkan kebijaksanaan dan keputusan yang tepat. Tindakan pengoordinasian ini meliputi pengawasan, pemberian nilai, pengarahan, dan bimbingan terhadap setiap personal organisasi dengan melibatkan pihak lain, seperti bimbingan dan konseling, guru yang menangani kurikulum, wali kelas, petugas tata usaha, petugas BP-3, komite sekolah, dan lain sebagainya.

\section{Penilik}

Penilik posisinya lebih tinggi dari pada kepala sekolah dalam melakukan supervisi. Tugas penilik adalah mengarahkan pencapaian tujuan supervisi yang tidak hanya memperbaiki mutu mengajar guru, tetapi juga membina pertumbuhan profesi guru dalam arti luas. Termasuk dalam hal ini adalah pengadaan fasilitas yang menunjang kelancaran proses belajar dan mengajar, peningkatan mutu pengetahuan dan keterampilan guru-guru, pemberian bimbingan dan pembinaan dalam hal implernentasi kurikulum, pemilihan dan penggunaan metode mengajar, alat-alat pengajaran, prosedur dan teknik evaluasi pengajaran,

7 Jamal Makmur Asmani, Tips Efektiv Supervise Pendidikan Sekolah (Jogjakarta: Diva press, 2012), cet. 1 hlm. 52 . 
dan lain sebagainya.

Dengan demikian, dapat dipahami bahwa kegiatan dan usaha pelaksanaan supervisi penilik adalah sebagai berikut:

a. Membangkitkan dan merangsang semangat guru-guru dan pegawai sekolah lainnya dalam menjalankan tugas masing-masing dengan sebaik-baiknya.

b. Berusaha mengadakan dan melengkapi alat-alat sekolah, termasuk pemenuhan macam-macam media instruksional yang diperlukan bagi kelancaran jalannya proses belajar dan mengajar yang baik.

c. Bersama guru-guru, ia berusaha mengembangkan, mencari, dan menggunakan rnetode baru dalam proses belajar dan mengajar yang lebih baik.

d. Membina kerjasarna yang baik dan harmonis dengan guru, murid, dan pegawai sekolah lainnya.

e. Berusaha mempertinggi mutu dan pengetahuan guru-guru dan pegawai sekolah.

f. Di antaranya, dengan mengadakan workshop, seminar, in-service training, atau up-grading. ${ }^{8}$

Lima tugas tersebut mengharuskan penilik untuk aktif menyerap pengetahuan dan mengikuti perkembangan inforrnasi. Supervisi penilik membangkitkan dan merangsang semangat guru-guru dan pegawai sekolah lainya dalam menjalankan tugas masing-masing dan sebaikbaiknya.

\section{Pengawas}

Dalam Islam istilah pengawasan biasa disebut dengan muraqabah atau muraqabatullah adalah suatu sifat mu'min yang dianggap mulia kerana dengannya seorang mu'min menjalani seluruh perjalanan hidupnya dengan perasaan bahwa dia senantiasa di dalam pengawasan Tuhannya. Dan sesuailah dengan materi yang sebelumnya telah kita bahas, dan mengenai pembahasan ini kami mulai dari kajian yang bersifat objektif menguraikan maksud 'muraqabah' menggunakan pendekatan tafsir mawdu`i, dengan mengkaji beberapa ayat al-Qur'an yang terkait dengan konsep ini.

Makna muraqabah berasal daripada perkataan 'raqaba' (رقب) yang berarti memerhati, menyaksikan dan mengawasi. Dan 'muraqabah' (مر اقبة) dan yang dimaksudkan disini adalah perhatian dan pengawasan. Kata

8 Herabuddin, Administrasi \& Supervisi Pendidikan (Bandung: Pustaka Setia, 2009), cet. 1, hal. 213-214

$244 \mid$ JURNAL LISAN AL-HAL 
kerja 'raqaba' sama artinya dengan 'ra'â' (رأى), 'rasada' (رصد (رصد) dan 'nazara' (نظر), cuma penggunaan setiap perkataan mungkin terdapat sedikit perbedaan. Muraqabah atau muraqabatullah bermakna pengawasan terhadap zat yang menjaga dirinya (Allah) dan menaruh perhatian yang sebesar-besarnya kepadaNya..$^{9}$ Maksud muraqabah juga di uraikan melalui hadith Jibril mengenai ihsan, yakni '... kamu beribadah kepada Allah seolah-olah kamu melihatNya, dan sekiranya kamu tidak melihatNya maka Dia melihat kamu' [HR.Muslim].

Perlu diketahui pula, bahwa menjalankan amanah dan menjaganya bukanlah perkara yang bisa dilakukan semudah membalik tangan. Allah telah menjelaskan tentang beratnya amanah di dalam firman-Nya:

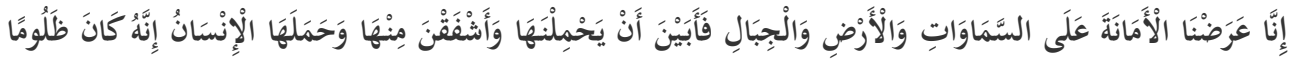

$$
\begin{aligned}
& \text { جَهُولاً }
\end{aligned}
$$

"Sesungguhnya, Kami telah menawarkan amanah Cyaitu menjalankan perintah-perintah Allah Subhanahu wa Ta'ala dan meninggalkan seluruh larangan-Nya) kepada seluruh langit dan bumi serta gunung-gunung. Maka, semuanya enggan untuk memikul amanah itu dan mereka khawatir akan mengkhianatinya, dan dipikullah amanat itu oleh manusia. Sesungguhnya manusia itu banyak berbuat dzalim dan amat bodoh." (Al-Ahzab: 72) ${ }^{10}$

Jelas bahwa yang kami maksudkan disini adalah memenuhi keperluan saudaranya berupa (amanah), bentuk amanah dalam pembahasan ini adalah berupa pengawasan atau mengawasai, dan menjalankan tugas sesuai dengan yang di bebankan, yang merupakan proses untuk mengetahui ada tidaknya penyimpangan dalam pelaksanaan agar segera dilakukan upaya perbaikan sehingga dapat memastikan bahwa aktivitas yang dilaksanakan sesuai dengan apa yang telah direncanakan atau tidak.

Namun secara umum tugas seorang pengawas dalam dunia pendidikan memiliki kedudukan lebih tinggi dari pada penilik. Sebab, ia adalah penilaian kinerja para penilik dan kepala sekolah dalam menjalankan fungsi mereka sebagai supervisor. Jadi, dapat dipahami bahwa kepala sekolah, penilik, dan pengawas memiliki tugas yang secara

9Jamâl al-Dîn al-Qâsimi al-Dimashqi, Bimbingan Untuk Mencapai Tingkat Mu'min Jilid 2 hlm. 570.

${ }^{10}$ Al Quraan, Al-Ahzab ayat: 72. 
substansial sama. Hanya saja wewenangnya berbeda. ${ }^{11}$ Dan tentang pengawas sekolah ini diatur pada peraturan menteri pendidikan nasional republik indonesia nomor 12 tahun 2007 tentang standar pengawas sekolah/madrasah (terlampir).

Pada dasarnya seorang pengawas itu mempunyai tugas berat, yaitu quality control (control kualitas) dan quality insurance (jaminan kualitas). Menurut Dedy Mulyasana, dengan system penjaminan mutu, diharapkan system tata kelola akan berkembang sesuai dengan standar mutu yang diharapkan. System penjaminan mutu ada dalam permendiknas Nomor 63 tahun 2009 tentang system penjaminan mutu pendidikan. ${ }^{12}$

Biasanya, pengawas sudah pernah menjadi kepala sekolah. Sehingga, ia memahami betul kompleksitas masalah yang dihadapi oleh kepala sekolah sebagai aktor kreatif di lapangan. Pengawas memberikan arahan, bimbingan, dan dorongan secara terus-menerus kepada sekolah. Hal ini dilakukan agar kepala sekolah tidak bosan dalam mengembangkan kualitas sekolahnya dari berbagai aspek, dan menerapkan manajemen profesional yang mengedepankan keterbukaan, akuntabilitas, integritas, kaderisasi, dan pemberdayaan.

Menurut Suaidin Usman, setiap hari, pengawas harus turun ke sekolah mendampingi guru keluar masuk kelas. Dan, hasilnya harus didiskusikan lagi melalui klinis. Itu hanya sebagian kecil dari tugas pengawas di bidang akademik. Belum ditambah pengawasan manajerial, berpindah dari satu sekolah ke sekolah lain, dan dari kecamatan ke kecamatan lain. ${ }^{13}$

Dengan demikian, kompetensi pengawas merupakan himpunan pengetahuan, kemampuan, dan keyakinan yang ditampilkan dalam tindakan untuk peningkatan mutu pendidikan/sekolah, Artinya, kompetensi tersebut berupa tingkah laku pengawas yang dapat diamati. Tingkah laku yang dimaksud diperoleh melalui pendidikan dan pelatihan sebelumnya. ${ }^{14}$

11 Herabuddin, Administrasi \& Supervisi Pendidikan (Bandung: Pustaka Setia, 2009), cet. 1, hlm. 213-214.

12 Dedy Mulyasana, pendidikan bermutu dan berdaya saing (Bandung: Rosda Karya, 2011), cet. 1, hlm. 129.

13 Republika.co.id, yang diakses pada 20 oktober 2015.

14 Mukhtar \& Iskandar, Orientasi Baru Supervise Pendidikan (Jakarta: gaung persada press, 2009), cet. 1, hlm. 97-98.

$246 \mid$ JURNAL LISAN AL-HAL 


\section{Dimensi Moralitas Supervisi}

Para guru merasa berada di situasi "win-loose" saat disupervisi; mengalami ketidakberdayaan, manipulasi, kekerasan seksual, dan stereotype sosial serta etnis. Puncaknya, perselisihan mereka dengan para supervisor cenderung mengarah kepada keputusan evaluatif berdasarkan bukti yang sangat sedikit. Akibatnya, silang pendapat antara supervisor dengan bawahannya dapat menghancurkan otonomi, kepercayaan diri sendiri dan integritas personal. Supervisi sering dipraktekkan oleh sejumlah supervisor sebagai sebuah tindakan yang tidak profesional, tidak manusiawi dan tidak etis.

Tujuan umum Supervisi adalah memberikan bantuan teknis dan bimbingan kepada guru dan staf agar personil tersebut mampu meningkatkan kualitas kinerjanya, dalam melaksanakan tugas dan melaksanakan proses belajar mengajar. secara operasional dapat dikemukakan beberapa tujuan konkrit dari supervisi pendidikan yaitu:

1. Meningkatkan mutu kinerja guru.

2. Membantu guru dalam memahami tujuan pendidikan dan apa peran sekolah dalam mencapai tujuan tersebut.

3. Membantu guru dalam melihat secara lebih jelas dalam memahami keadaan dan kebutuhan siswanya.

4. Membentuk moral kelompok yang kuat dan mempersatukan guru dalam satu tim yang efektif, bekerjasama secara akrab dan bersahabat serta saling menghargai satu dengan lainnya.

5. Meningkatkan kualitas pembelajaran yang pada akhirnya meningkatkan prestasi belajar siswa.

6. Meningkatkan kualitas pengajaran guru baik itu dari segi strategi, keahlian dan alat pengajaran.

7. Menyediakan sebuah sistim yang berupa penggunaan teknologi yang dapat membantu guru dalam pengajaran.

8. Sebagai salah satu dasar pengambilan keputusan bagi kepala sekolah untuk reposisi guru.

9. Meningkatkan keefektifan kurikulum sehingga berdaya guna dan terlaksana dengan baik

10. Meningkatkan keefektifan dan keefesiensian sarana dan prasarana yang ada untuk dikelola dan dimanfaatkan dengan baik sehingga mampu mengoptimalkan keberhasilan siswa

11. Meningkatkan kualitas pengelolaan sekolah khususnya dalam mendukung terciptanya suasana kerja yang optimal yang selanjutnya siswa dapat mencapai prestasi belajar sebagaimana yang diharapkan. 
12. Meningkatkan kualitas situasi umum sekolah sehingga tercipta situasi yang tenang dan tentram serta kondusif yang akan meningkatkan kualitas pembelajaran yang menunjukkan keberhasilan lulusan.

\section{E. Supervisi Sebagai Tindakan Moral}

Norma moral bukan merupakan pembatasan kebebasan manusia, namun norma itu berusaha melindungi, mengolah nilai, dan membantu manusia untuk memperoleh kesejahteraan dalam hidupnya. Norma yang tidak berdasarkan nilai dan yang tidak menegaskan keharusan yang dianggap penting dengan sendirinya akan mengalami kehilangan kekuatan moral yang mewajibkan. Makna norma moral berasal dari nilai. Seandainya tak bernilai, maka norma itu kehilangan makna. Walaupun begitu, norma moral mengandung ambivalensi. Dari satu segi, norma moral mengungkapkan nilai dan dari segi lain norma moral adalah "persembunyian" nilai. ${ }^{15}$ Nilai moral merupakan nilai yang paling tinggi. Karena nilai moral berkaitan dengan tanggung jawab dan tuntutan suara hati. Oleh karena itu nilai moral mewajibkan secara mutlak dan sangat perlu diterapkan pada nilai-nilai umum. ${ }^{16}$

Nilai-nilai moral biasanya diekspresikan sebagai pernyataan yang mendeskripsikan objek-objek atau ciri-ciri objek yang bernilai, semacam "kejujuran itu baik" dan "ketidakadilan itu buruk". Standar moral pertama kali terserap ketika masa kanak-kanak dari keluarga, teman, pengaruh kemasyarakatan, seperti: sekolah, televisi, majalah, music dan perkumpulan. Sedangkan hakekat standar moral meliputi: standar moral berkaitan dengan persoalan yang kita anggap akan merugikan secara serius atau benar-benar akan menguntungkan manusia; standar moral tidak dapat ditetapkan atau diubah oleh keputusan dewan otoritatif tertentu dan standar moral harus lebih diutamakan daripada nilai lain termasuk (khususnya) kepentingan diri.

Sedangkan fungsi fungsi norma moral itu dalam kehidupan bersama meliputi empat hal, yakni: pertama, membungkus nilai-nilai moral (cinta kasih, kebaikan, kejujuran, keadilan, kemanusiaan) yang menjadi orientasi (orient), kedua, mengingatkan manusia untuk melakukan yang baik untuk diri dan sesama, ketiga, menarik perhatian (orang jadi tahu) pada masalah-masalah yang kurang diperhatikan dan keempat, agar manusia tidak hanyut oleh perasaan, misalnya jangan

15 William Chang, Pengantar Teologi Moral (Yogyakarta: Kanisius, 2001), hlm. 86.

${ }^{16}$ http://fra daus.staff.gunadarma.ac.id/Downloads/files/9068/etika+11.doc

$248 \mid$ JURNAL LISAN AL-HAL 
membunuh, dengan norma ini manusia mengolah emosinya. ${ }^{17}$ Mengerti dengan baik akan fungsi norma ini kiranya tidak lagi ada orang jatuh pada pemikiran atau anggapan bahwa norma moral membatasi tindakan seseorang. Konsep berpikir ini perlu dijadikan landasan perilaku dalam melaksanakan berbagai pekerjaan.

Para guru merasa berada di situasi "win-loose" saat disupervisi; mengalami ketidakberdayaan, manipulasi, dan stereotype sosial serta etnis. Puncaknya, perselisihan mereka dengan para supervisor cenderung mengarah kepada keputusan evaluative berdasarkan bukti yang sangat sedikit. Akibatnya, silang pendapat antara supervisor dengan bawahannya dapat menghancurkan otonomi, kepercayaan diri sendiri dan integritas personal. Supervisi sering dipraktekkan oleh sejumlah supervisor sebagai sebuah tindakan yang tidak profesional, tidak manusiawi dan tidak etis. Jika isu-isu negatif ini mendominasi aktivitas supervisi, akan menumbangkan berbagai kemungkinan komunikasi yang terbuka, dapat dipercaya dan profesional serta dapat memicu kata-kata manipulatif dari supervisor dan guru.

Jika supervisi menjadi tindakan moral, maka harus memperhatikan integritas dari supervisor dan yang disupervisi. Artinya, hubungan timbal balik antara supervisor dan guru mencerminkan sikap saling percaya, terbuka dan fleksibel dalam rangka memberi kesempatan kepada kedua orang tersebut untuk berbicara berdasarkan integritas yang dimiliki dan mendorong masing-masing orang untuk menghargai integritas orang lain. Hubungan timbal balik tersebut harus dimulai dengan sebuah diskusi yang jujur mengenai hal-hal apa saja yang sepenuhnya akan membantu para guru dan siswa.

Agar hal ini dapat terjadi, para supervisor harus mencari jalan bagaimana menggali kondisi dalam rangka membangun dan mempertahankan kepercayaan, kejujuran dan komunikasi yang terbuka. Artinya, supervisor harus berdiskusi dengan para guru mengenai prosedur yang harus dipatuhi, hak dan kewajiban yang harus dijabarkan, siapa mengontrol apa, kebutuhan siapa yang harus dilayani, tujuan dari hubungan timbal balik, dan lain sebagainya. Diskusi ini dengan sendirinya adalah sebuah bentuk tindakan moral, sebuah negosiasi dari tuntunan yang harus diikuti sehingga keadilan dan kejujuran dapat diperhatikan dengan seksama. tahun, 26.

${ }^{17}$ Largus Nadeak, Diktat Moral Diktat Moral Fundamental. Pematangsiantar: tanpa \begin{tabular}{l|l} 
JURNAL LISAN AL-HAL & 249
\end{tabular} 


\section{F. Strategi Peningkatan Moral di Sekolah/Madrasah}

Praktek sekolah dalam penilaian dan ujian, pemilihan textbook atau pemilihan pembicara dapat dipertanyakan dari segi keadilan, kesamaan, penghargaan terhadap pluralisme budaya, atau kriteria moral lain. Akibat dari kebijakan pemakaian seragam, penamaan "anak berbakat" atau "anak yang memiliki keterbatasan", ketidakhadiran topik penting dan beberapa hal di textbook, proses penghitungan rangking, ketidakhadiran berbagai alternatif penilaian siswa, dan berbagai prosedur institusional lainnya dapat memberi implikasi moral.

Ketika prosedur institusional menjadi hal yang lebih penting daripada aspek manusia yang dilayani oleh institusi tersebut, bahaya ancaman moral muncul. Lingkungan institusional menjadi ancaman bagi kehidupan manusia. Nilai-nilai seperti keseragaman, kemampuan memprediksi, efisiensi, kepatuhan dan ketegasan dapat cenderung menghapus nilai-nilai lain seperti kebebasan dari kesadaran, kreativitas, keragaman, inovasi, pengambilan resiko, dan kemampuan individu. Padahal, prosedur institusional seharusnya mampu melayani kebutuhan manusia.

Posisi supervisor berbeda dari posisi institusional guru. Tanggung jawab utama guru terhadap siswa adalah mengamati siswa apakah mereka telah mempelajari apa yang telah ditetapkan oleh guru dan komunitas sekolah. Tanggung jawab supervisor lebih besar bagi keseluruhan komunitas yaitu melihat apakah tujuan umum sekolah telah tercapai. Supervisor biar bagaimanapun harus menikmati berbagai kesempatan untuk menciptakan dan mempertahankan pembicaraan dengan berbagai grup dalam komunitas sekolah.

Ada baiknya bila kita memahami dimensi moral supervisi dengan melihat lebih dekat dimensi moral yang tercakup dalam pengajaran yang ideal. Para guru sepakat bahwa pengajaran yang ideal berarti memahami konsep umum profesionalisme. Saat berbicara mengenai profesionalisme, perhatian tertuju ke isu kompetensi. Namun, profesional tidak berarti hanya kompeten di bidangnya tetapi juga banyak "hal lain", seperti seorang profesional menikmati kepuasan batin karena mereka dipercaya. Kepercayaan tidak bisa didapat dengan mudah hanya dengan kompetensi.

Setidaknya terdapat empat hal yang dikaitkan dengan sifat profesional : 1) Komitmen untuk mempraktekkan pengajaran yang patut dicontoh; 2) Komitmen untuk mempraktekkan pengajaran menuju hasil akhir yang bernilai social, 3) Komitmen yang tidak hanya melekat dalam individu namun juga bagi praktek pengajaran itu sendiri; dan 4) Komitmen untuk etika kepedulian. Empat dimensi sifat profesional 
tersebut menyediakan dasar pengembangan sistem norma yang sangat kuat sehingga mampu mentransformasikan supervisi seperti yang saat ini sering digunakan. Untuk alasan ini, pembentukkan sisi kebaikan dari profesionalisme harus menjadi prioritas utama dalam supervisi.

Sebagai contoh, komitmen untuk mempraktekkan pengajaran yang patut dicontoh berarti menerapkan penghapusan cara pengajaran yang tidak tepat, mengikuti perkembangan praktek pengajaran, meneliti cara pengajaran praktek milik seseorang, melakukan eksperimen pendekatan baru, dan berbagi informasi mengenai pendapat seseorang tentang pengajaran. Dimensi ini akan membuat guru bertanggungjawab atas pengembangan profesionalisme mereka sendiri, kemudian mengurangi peran orang lain dalam merencanakan dan mengimplementasikan program pengembangan bagi mereka.

Dimensi kedua, komitmen untuk mempraktekkan pengajaran menuju hasil akhir yang bernilai sosial melambangkan komitmen untuk melayani siswa dan orangtua serta setuju terhadap nilai-nilai dan tujuan sekolah. Dimensi ketiga, komitmen yang tidak hanya melekat dalam individu namun juga bagi praktek pengajaran itu sendiri, mendorong para guru untuk memperluas pengetahuannya. Komitmen seperti itu mengisyaratkan pengajaran ditransformasikan dari praktek individual menjadi praktek kolektif. Contoh praktek kolektif adalah tidak diperbolehkan seorang guru mengajar siswa yang mengalami kesulitan belajar tanpa disertai rasa kepedulian atau tanpa menawarkan bantuan. Atau, tidak diperbolehkan seorang guru memiliki pendangan baru tentang pengajaran tapi tidak membaginya ke orang lain.

\section{G. Simpulan}

Peran penting supervisi pendidikan adalah sebagai pembinaan kearah pebaikan situasi pendidikan. Perbaikan ini difokuskan pada kinerja pembelajaran, sehingga guru secara profesional memberikan bantuan dan layanan. Dimensi moral supervisi harus memperhatikan integritas dari supervisor dan yang disupervisi. Artinya, hubungan timbal balik antara supervisor dan guru mencerminkan sikap saling percaya, terbuka dan fleksibel dalam rangka memberi kesempatan kepada kedua orang tersebut untuk berbicara berdasarkan integritas yang dimiliki dan mendorong masing-masing orang untuk menghargai integritas orang lain.

Supervisi sebagai tindakan moral bukan merupakan pembatasan kebebasan manusia, namun norma itu berusaha melindungi, mengolah nilai, dan membantu manusia untuk memperoleh kesejahteraan dalam hidupnya. Strategi peningkatan moral Ada baiknya bila kita memahami

$$
\text { JURNAL LISAN AL-HAL } \mid 251
$$


dimensi moral supervisi dengan melihat lebih dekat dimensi moral yang tercakup dalam pengajaran yang ideal. Para guru sepakat bahwa pengajaran yang ideal berarti memahami konsep umum profesionalisme. Saat berbicara mengenai profesionalisme, perhatian tertuju ke isu kompetensi. Namun, profesional tidak berarti hanya kompeten di bidangnya tetapi juga banyak "hal lain", seperti seorang profesional menikmati kepuasan batin karena mereka dipercaya. Kepercayaan tidak bisa didapat dengan mudah hanya dengan kompetensi.

\section{DAFTAR PUSTAKA}

A. Piet Sahertian, konsep dasar dan teknik supervise pendidikan dalamrangka pengembangan SDM Jakarta: rineka cipta, 2008 .

Gunawan, Ary H . Administrasi Sekolah Jakarta: Rineka Cipta, 2001.

Badan Standar Nasional Pendidikan, Standar Pengawas Sekolah Madrasah Jakarta: BSNP, 2007.

Chang, William, Pengantar Teologi Moral. Yogyakarta: Kanisius, 2001.

Mulyasana, Dedy . Pendidikan Bermutu dan Berdaya Saing, Bandung: Rosda Karya, 2011.

Purwanto, Ngalim. Administrasi dan Supervisi Pendidikan. Bandung: PT. Remaja Rosdakarya. Cet. Ke-16. 2006.

E. Mulyasa, Manajemen \& Kepemimpinan Kepala Sekolah Jakarta: bumi aksara, 2011, cet.1

Herabuddin, Administrasi \& Supervisi Pendidikan Bandung: Pustaka Setia, 2009

http://fra_daus.staff.gunadarma.ac.id/Downloads/files/9068/etika+11.do $\mathrm{c}$

al-Qâsimi al-Dimashqi, Jamâl al-Dîn. Bimbingan Untuk Mencapai Tingkat Mu'min. Jilid 2 .

Asmani, Jamal Makmur. Tips Efektiv Supervise Pendidikan Sekolah Jogjakarta: Diva press, 2012.

Purwanto, M. Ngalim. Administrasi dan Supervise Pendidikan. Bandung. Remaja Rosdakraya, 2002.

Maryono, Dasar Dan Teknik Supervisi Pendidikan, Jogjakarta: Ar Ruzz Media. 2011.

Hasyim Asv'ari, Muhammad. Adab al-AJim wa aJ-Mula'alim. Jombang: Ma'had al-lslami al-Salafi.

Mukhtar \& Iskandar, Orientasi Baru Supervise Pendidikan Jakarta: gaung persada press, 2009.

Chatib, Munif. Gurunya Manusia menjadikan semua anak istimewa dan

$252 \mid$ JURNAL LISAN AL-HAL 
semua anak juara). Bandung, Kaifa Mizan Pustaka: 2013.

Chatib, Munif. Sekolahnya Manusia Bandung, Kaifa Mizan Pustaka: 2012.

Mustaqim, Supervisi Pendidikan Agama Islam. Semarang: Media Group. 2012.

Nadeak, Largus. Diktat Moral Fundamental I Pematangsiantar: tanpa tahun.

Nurhayati, Djamas. Pedoman Pelaksanaan Supervisi, Jakarta: Departemen Agama RI Direktorat Jenderal Pembinaan Kelembagaan Agama Islam. 2000.

Pieta, Sahertian. Konsep Dasar dan Teknik Supervisi Pendidikan dalam Rangka Pengembangan Sumber Daya Manusia, Jakarta: Rineka Cipta. 2000.

Syaiful, Sagala. Kemampuan Profesional Guru dan Tenaga Kependidikan, Bandung: CV. ALFABETA. 2011.

Sahertian, Piet A. Dan Mataheru Dip. Ed. Ad, Frans. 1981. Prinsip dan Teknik Supervisi Pendidikan, Surabaya: Usana Offset Printing.

Suhardan, Dadang. Supervisi profesional, Bandung: CV. ALFABETA. 2010.

Sujana, Nana. Supervisi Akademik; membina profesionalisme guru melalui supervisi klinis . Jakarta : LPP Bina Mitra. 2008.

Mahmud, Sulton. Manajemen Profesi Kependidikan.Jember : LPMPK. Cet. ke- 3 2012. Sulu Lipu La Sulo. Supervisi Klinis Pendekatan Bimbingan dalam Penyelenggaraan Program Pengalaman Lapangan (PPL). Jakarta: Depdikbud Dirjen Dikti PPGSM. 1998.

Al-Hasan, Yusuf. Pedoman Pengawasan Untuk Madrasah dan Sekolah Umum. Jakarta : CV. Mekar Jaya. Cet. Ke- 1. 2002. 
"Arah Baru Supervisi Pendidikan"

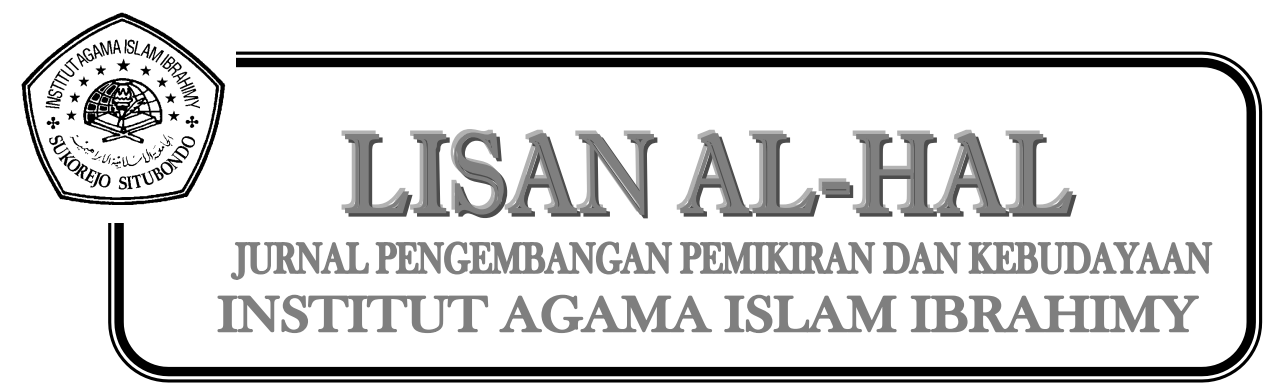

254 JURNAL LISAN AL-HAL 